\title{
IgM antibody against hepatitis $B$ core antigen (IgM anti-HBc): diagnostic and prognostic significance in acute HBsAg positive hepatitis
}

\author{
C LAVARINI，P FARCI， E CHIABERGE，V VEGLIO，D GIACOBBI，G BEDARIDA， G SUSANI, \\ $M$ TOTI, P ALMI, N CAPORASO, C DEL VECCHIO BLANCO, M RIZZETTO
}

\begin{abstract}
IgM antibody against hepatitis $B$ core antigen (IgM anti-HBc), a marker of recent hepatitis $B$ virus infection, was sought by radioimmunoassay in sera diluted $1 / 4000$ from 376 patients presenting to four centres in Italy with acute, apparently type $B$ hepatitis (hepatitis $B$ surface antigen (HBsAg) positive).

In 320 patients $(85 \%)$ a positive IgM anti-HBc test result confirmed that hepatitis was due to primary infection with hepatitis $B$ virus. In the remaining 56 patients absence of the $\operatorname{IgM}$ marker indicated that they were previously unrecognised long term carriers of HBsAg. Further serum analysis often showed delta infection and occasionally hepatitis $A$ or cytomegalovirus infection as the true cause of their illness. After six to eight months circulating $\mathrm{HBsAg}$ persisted in 38 of 45 patients $(84 \%)$ without IgM anti-HBc but in only six of 150 patients $(4 \%)$ with the $\operatorname{IgM}$ antibody $(p<0.0001)$.

A negative IgM anti-HBc test result in patients with acute HBsAg positive hepatitis points to a factor other than hepatitis $B$ virus as the cause of the liver damage and predicts the carriage of $\mathrm{HBs} \mathrm{Ag}$.
\end{abstract}

\section{Introduction}

Testing with sensitive immunoassays for $\operatorname{IgM}$ antibody against hepatitis $B$ core antigen (IgM anti-HBc) shows that reactivity is invariably present in acute hepatitis B but usually absent or detectable only at low titres in asymptomatic carriers of hepatitis B surface antigen (HBsAg) ${ }^{1-8}$ Longitudinal studies confirm that $\mathrm{IgM}$ anti-HBc is increased early during primary hepatitis $\mathrm{B}$ virus infection and then declines in a few months regardless of the persistence of circulating $\mathrm{HBsAg} .{ }^{4}$ :

In view of the temporal relation to recent hepatitis $B$ virus infection measurement of the $\operatorname{IgM}$ antibody might help to distinguish true hepatitis $\mathrm{B}$ from non-B hepatitis occurring in previously unrecognised carriers of $\mathrm{HBsAg}$; many of these patients presenting with an acute liver illness are likely to be diagnosed as hepatitis B on finding $\mathrm{HBsAg}$ in the serum.

To determine the clinical value of $\operatorname{IgM}$ anti-HBc, this serum marker was measured by radioimmunoassay in 376 patients with

Divisione di Gastroenterologia, Molinette, Torino, Italy

C LAVARINI, BSC

P FARCI, MD

E CHIABERGE, research fellow

$\checkmark$ VEGLIO, MD

D GIACOBBI, $M D$

G BEDARIDA, $M D$

G SUSANI, MD

$M$ TOTI, MD

P ALMI, MD

N CAPORASO, $M D$

C DEL VECCHIO BLANCO, MD

M RIZZETTO, $M D$

Correspondence to: Dr M Rizzetto, Divisione di Gastroenterologia, Ospedale Molinette, 10126 Torino, Italy. acute, apparently type $\mathrm{B}$ hepatitis ( $\mathrm{HBs} \mathrm{Ag}$ positive) presenting to centres in Italy serving populations with various prevalences of carriage of $\mathrm{HBsAg}$. The sensitivity of the test in discriminating recent from old infection with hepatitis $B$ virus was optimised using sera from patients with true acute hepatitis $B$ and from asymptomatic long term carriers of $\mathrm{HBs} \mathrm{Ag}$.

\section{Materials and methods}

DETECTION OF IgM ANTI-HBC

$\operatorname{IgM}$ anti-HBc was measured with a $\mu$ capture radioimmunoassay, whose specificity has been described. ${ }^{4}$ The test was performed on beads coated with antihuman IgM (AU-IGMK, Sorin Biomedica, Saluggia, Italy) diluted $1 / 25000$ in phosphate buffered saline 150 $\mathrm{mmol} / 1$, $\mathrm{pH} 7 \cdot 4$. Coated beads were incubated overnight at room temperature with $200 \mu$ l test serum diluted in phosphate buffered saline containing $4{ }^{\prime \prime}{ }^{\prime}$ bovine serum albumin and $1 \mathrm{mmol}$ edetic acid (EDTA) $/ 1(29.2 \mathrm{mg} / 100 \mathrm{ml})$. After washing, beads were incubated for three hours at $45^{\circ} \mathrm{C}$ with $50 \mu$ standard hepatitis B core antigen $\left(\mathrm{HBcAg}\right.$ ) plus $150 \mu \mathrm{l}^{12.5} \mathrm{I}$ labelled $\mathrm{IgG}$ anti-HBc (about $3 \times 10^{5}$ counts $/ \mathrm{min} /$ well $) ; 10 \mu \mathrm{l}$ of a $3^{\prime \prime}$, solution of Nonidet P40 was added to each bead. After a final washing in deionised water the beads were counted for residual radioactivity. Sera were considered positive for IgM anti-HBc if the number of counts/min recovered from beads incubated with test serum was $2 \cdot 1$ times the average number of counts in negative controls. Titres of the antibody were expressed as the end point positive dilution.

$\mathrm{HBcAg}$ was extracted from postmortem liver of a patient who had been receiving dialysis, which displayed strong $\mathrm{HBcAg}$ staining on immunofluorescence; serum from the patient contained a low titre of anti-HBc. Blocks of liver were cut, washed in cold phosphate buffered saline, resuspended in TKM buffer (trometamol (TRIS) $5 \mathrm{mmol} / 1$ $(60.6 \mathrm{mg} / 100 \mathrm{ml}), \mathrm{KCl} 25 \mathrm{mmol} / 1(186.4 \mathrm{mg} / 100 \mathrm{ml}), \mathrm{MgCl}_{2}$ $2 \mathrm{mmol} / 1(19 \cdot 0 \mathrm{mg} / 100 \mathrm{ml}), \mathrm{pH} 7 \cdot 4)$, homogenised, and sonicated for 30 seconds. The homogenate was left stirring overnight at $4 \mathrm{C}$ and then centrifuged for 30 minutes at $19000 \mathrm{rpm}$ with a fixed angle type 35 Beckman rotor. The supernatant was titred with a microtitre radioimmunoassay specific for $\mathrm{HBcAg}^{9}$ and divided into aliquots; the appropriate dilution was used as standard $\mathrm{HBcAg}$ for routine testing.

IgG for labelling with ${ }^{125} \mathrm{I}$ was obtained by DE 52 chromatography from the serum of a chronic carrier of HBsAg with a high titre of anti-HBc and negative for antibody against $\mathrm{HBeAg}$.

\section{SERUM CONTROLS}

Sera used to establish the optimal sensitivity of the IgM anti-HBc assay in discriminating recent from old hepatitis $B$ virus infection were obtained from 30 patients with true acute type B hepatitis and from 30 asymptomatic patients with chronic hepatitis $B$ virus infection of long standing.

Patients with acute hepatitis type B were medical or laboratory staff known to have been seronegative for HBsAg before the episode of acute hepatitis accompanied by the appearance of HBsAg in serum; in each case the illness resolved uneventfully with seroconversion to anti-HBs. Serial samples of serum taken during the hepatitic and convalescent phases up to 7-10 weeks from the onset of the disease were available from all.

Patients with asymptomatic chronic hepatitis B virus infection had been known carriers of HBsAg for two to five years before blood sampling; all had normal liver histologically, 15 had HBeAg in the serum, and 15 had antibody against $\mathrm{HBeAg}$. 
OTHER ASSAYS

HBsAg and antibody (anti-HBs), HBeAg and antibody (anti-HBe), and $\operatorname{IgM}$ antibody against hepatitis $A$ virus (IgM anti-HA) were tested with commercial radioimmunoassays (AUSRIA II, AUSAB, KIT HBe, HAVAB-M ; Abbott Laboratories, Chicago). IgM antibody against cytomegalovirus (IgM anti-CMV) was measured by indirect immunofluorescence (Electro Nucleonics Laboratories Inc, Columbia, $\mathrm{Md})$. Delta antigen ( $\delta \mathrm{Ag}$ ) and antibody of IgG type (anti- $\delta$ ) and IgM type (IgM anti- $\delta$ ) were measured by radioimmunoassay. ${ }^{1011}$

\section{PATIENTS}

IgM anti-HBc was sought in a total of 376 patients with apparently type B hepatitis who had presented consecutively over one to three years to medical centres in Italy. Centres were chosen from areas with different rates of carriage of $\mathrm{HBsAg}$ in the populations. There were 89 patients from Torino (Piedmont), 85 from Lodi (Lombardy), 90 from Siena (Tuscany), and 112 from Napoli (Campania); rates of carriage of $\mathrm{HBsAg}$ in these areas were reported as $1.7 \%, 6.2 \%, 1.2 \%$, and $4.3 \% .1213$

The diagnosis was based on presentation with symptoms suggestive of acute viral hepatitis and an alanine aminotransferase activity 10 times or more the normal value, a normal serum protein concentration, and HBsAg in serum. None of the patients had evidence of previous liver disease; the acute illness was fatal in one patient. Serum was obtained within one week after admission to hospital. A follow up serum sample was obtained from some of the patients six to eight months after the onset of hepatitis and examined for $\mathrm{HBsAg}$ and alanine aminotransferase activity.

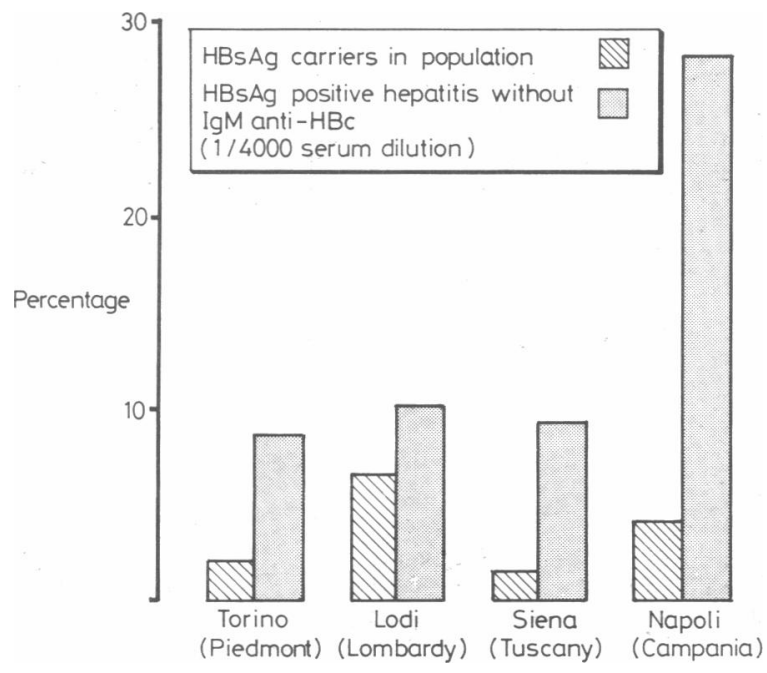

Percentage prevalence of HBsAg carriers and rate of IgM anti$\mathrm{HBC}$ negative hepatitis $\mathrm{B}$ in four medical centres in Italy.

\section{Results}

CONTROL SERA

Sera from controls with true acute hepatitis B and with chronic asymptomatic hepatit is B virus infection were titred for IgM anti-HBc in 10 -fold dilutions. Controls with hepatitis $B$ were all positive at a titre of $1 / 10^{5}$ or higher in the acute phase of the illness, decreasing to not less than $1 / 10^{4}$ within two months after onset. Long term carriers of $\mathrm{HBsAg}$ were all negative at a dilution higher than $1 / 5 \times 10^{2}$. A 1/4000 dilution of serum was therefore used to screen for IgM anti$\mathrm{HBc}$. Positive sera were titred to end point.

\section{IGM ANTI-HBC IN ACUTE HEPATITIS}

Of the 376 patients with acute, apparently type B hepatitis, 320 $(85 \%)$ were positive for $\operatorname{IgM}$ anti-HBc at titres between $1 / 10^{5}$ and $1 / 10^{6}$ and $56\left(15^{\%}\right)$ were negative at a serum dilution of $1 / 4000$. Of the $56 \mathrm{IgM}$ anti-HBc negative patients, seven were among the 89 patients from Torino $(7 \cdot 8 \%$ ), nine among the 85 patients from Lodi
$(10.5 \%)$, eight among the 90 from Siena $(8 \cdot 8 \%)$, and 32 among the 112 from Napoli $(28 \cdot 5 \%)$.

There were 11 parenteral drug addicts and two patients receiving dialysis in the IgM anti-HBc negative group; characteristic epidemiological features were not observed in the others.

SEROLOGICAL CHARACTERISTICS OF ACUTE HBSAg POSITIVE HEPATITIS WITH AND WITHOUT IGM ANTI-HBC

Sera of 239 patients with $\operatorname{IgM}$ anti-HBc and of the 56 patients without $\mathrm{IgM}$ anti-HBc were examined for the $\mathrm{HBe}$ antigen-antibody system.

$\mathrm{HBeAg}$ was detected in $171(71 \%)$ of the 239 patients with IgM anti-HBc and in $15(26 \%)$ of the 56 patients without the IgM marker. Anti-HBe was detected in $60(25 \%)$ of the 239 patients with IgM anti-HBc and in $38(68 \%)$ of the 56 without the IgM marker. HBeAg was significantly associated with the presence of $\operatorname{IgM}$ anti-HBc ( $p<0.001 ; 95 \%$ confidence limit of the difference: $31 \cdot 8-57 \cdot 7)$; anti-HBe was significantly associated with the absence of $\operatorname{IgM}$ antiHBc ( $p<0.001 ; 95 \%$ confidence limit of the difference: 29.3-56.2).

IgM anti-HBc negative sera were further screened for IgM anti-HA, IgM anti-CMV, and markers of delta infection. One patient $(1.7 \%)$ had IgM anti-CMV, three $(5.3 \%)$ had IgM anti-HA, and $32(57 \%)$ had markers of delta infection. Delta markers were: $\delta \mathrm{Ag}$ in one patient, $\operatorname{Ig} M$ anti- $\delta$ in four patients, and $\operatorname{IgM}$ plus IgG anti- $\delta$ in 27 patients.

Follow up serum samples were obtained six to eight months after the onset of hepatitis from 45 patients without IgM anti-HBc and from 150 with the $\operatorname{IgM}$ marker. $\mathrm{HBsAg}$ was found in the serum of 38 $(84 \%)$ of the 45 patients without the marker and in six $(4 \%)$ of the 150 patients with the marker (table). There was a significant association between the absence of $\operatorname{IgM}$ anti-HBc at the onset of hepatitis and the persistence of $\mathrm{HBsAg}$ at follow up ( $p<0.0001 ; 95 \%$ confidence limit of the difference: $69 \cdot 4-91 \cdot 5)$. Raised alanine aminotransferase activity indicated chronicity of liver disease in 31 of the $38 \mathrm{IgM}$ anti-HBc negative patients with persistent $\mathrm{HBs}$ antigenaemia and in four of the six patients positive for $\operatorname{IgM}$ anti-HBc. At follow up alanine aminotransferase activity was normal in all $144 \mathrm{IgM}$ anti-HBc positive patients whose hepatitis $B$ virus infection cleared.

Scrological follow up of $\mathrm{HBs} A g$ positive hepatitis with and without IgM anti-HBc

\begin{tabular}{|c|c|c|c|}
\hline & \multirow{2}{*}{$\begin{array}{l}\text { No of patients } \\
\text { followed up }\end{array}$} & \multicolumn{2}{|c|}{$\begin{array}{l}\text { Serum HBsAg after } \\
\text { six to eight months }\end{array}$} \\
\hline & & Positive & Negative \\
\hline $\begin{array}{l}\text { IgM anti-HBc positive } \\
\text { IgM anti-HBc negative }\end{array}$ & $\begin{array}{r}150 \\
45\end{array}$ & $\begin{array}{r}6^{*} \\
38+\end{array}$ & $\begin{array}{r}144 \\
7\end{array}$ \\
\hline
\end{tabular}

* Includes four with abnormal alanine aminotransferase activity.

+ Includes 31 with abnormal alanine aminotransferase activity.

\section{Discussion}

In this study optimal discrimination between recent and old hepatitis $B$ virus infection was achieved with a radioimmunoassay for IgM anti-HBc performed in sera diluted $1 / 4000$, at which controls with acute hepatitis $B$ yielded invariably positive reactions, wheras chronic asymptomatic carriers of $\mathrm{HBsAg}$ gave consistently negative results.

In most of the patients presenting with acute HBsAg hepatitis the finding of IgM anti-HBc confirmed that the illness was due to primary infection with hepatitis $B$ virus. In each of the series examined, however, some of the patients lacked the IgM marker and were therefore considered to be previously unrecognised carriers of HBsAg presumably suffering from non-B hepatitis. In keeping with this, on admission to hospital many of them had circulating anti-HBe, which represents a marker of inactive infection ${ }^{14} ; \mathrm{HBeAg}$ was usually found in the serum of patients positive for IgM anti-HBc as typical of classical acute hepatitis B. ${ }^{14}$

Further serological analysis often disclosed delta infection and occasionally hepatitis A or cytomegalovirus infection as the true cause of the illness. An additional factor could not be identified in some of the patients; undefined non- $A$ non- $B$ viruses of 
hepatitis or reactivation of the latent hepatitis B virus infection may have been implicated as the possible cause of the hepatitic episode.

As expected, during follow up $\mathrm{HBs} A \mathrm{~g}$ persisted in the serum of many patients without the IgM antibody, whereas among patients with the IgM marker the antigen cleared in almost all. Clinically, therefore, a negative IgM anti-HBc test result predicts the carriage of HBsAg.

Our data show that testing for $\operatorname{IgM}$ anti-HBc is important in patients developing an apparent hepatitis $\mathrm{B}$ of unrelenting course: a similar clinical entity is mimicked by progressive non-B hepatitis in previously unrecognised carriers of $\mathrm{HBs} A g$, and in this study accounted for most of the cases of $\mathrm{HBsAg}$ hepatitis destined to become chronic. A negative IgM anti-HBc test result should prompt search for a cause of the liver damage other than hepatitis B virus.

The magnitude of the problem of false hepatitis $B$ is likely to be proportional to the prevalence of carriage of $\mathrm{HBsAg}$ in the population. In our study, however, the relation was not numerical, as in each series examined the proportion of patients negative for $\operatorname{IgM}$ anti-HBc was higher than the local rate of carriage.

Though a minority of the $\operatorname{IgM}$ anti-HBc negative patients were drug addicts or patients receiving dialysis and therefore heavily exposed to blood borne hepatitis viruses, an epidemiological factor was not obvious in the others. The implication might be that the HBsAg carrier state determines an increased biological susceptibility to hepatitis by multiple viral and possibly non-viral factors. This was shown for delta, a defective virus that is rescued and activated only by HBs antigenaemia. ${ }^{15}$

\author{
References \\ 1 Tedder RS, Wilsom-Croome R. IgM antibody response to the hepatitis B \\ core antigen in acute and chronic hepatitis B. $\mathcal{f}$ Hyg (Lond) $1981 ; 86$ : \\ 163-72. \\ ${ }^{2}$ Kryger P, Mathiesen LR, Aldershvile J, Nielsen JO, and the Copenhagen
}

hepatitis acuta programme. Presence and meaning of anti-HBc IgM as determined by ELISA in patients with acute type $B$ hepatitis and healthy HBsAg carriers. Hepatology $1981 ; 1: 233-7$.

${ }^{3}$ Roggendorf M, Deinhardt F, Frosner GG, Scheid R, Bayeri B, Zachoval $R$. Immunoglobulin $M$ antibodies to hepatitis $B$ core antigen: evaluation of enzyme immunoassay for diagnosis of hepatitis B virus infection. 7 Clin Microbiol 1981;13:618-26.

- Lavarini C, Crivelli O, Smedile A, et al. Radioimmunoassay detection of $\mathrm{IgM}$ antibodies to hepatitis B core antigen in $\mathrm{HBsAg}$ liver disease. Boll Ist Sieroter Milan 1982;61:210-7.

Feinmann SV, Overby LR, Berris B, Chau K, Schable CA, Maynard JE. The significance of $\operatorname{IgM}$ antibodies to hepatitis $B$ core antigen in hepatitis B carriers and hepatitis B associated chronic liver disease. Hepatology $1982 ; 2: 795-9$

${ }^{6}$ Shimizu $M$, Ohyama $M$, Takahashi $Y$, et al. Immunoglobulin $M$ antibody against hepatitis B core antigen for the diagnosis of fulminant type B hepatitis. Gastroenterology 1983;84:604-10.

' Chau KH, Hargie MP, Decker RH, Mushawar IK, Overby LR. Serodiagnosis of recent hepatitis $B$ infection by IgM class anti-HBc. Hepatology 1983;3:142-9.

Banninger P, Altorfer J, Frosner GG, et al. Prevalence and significance of anti-HBc IgM (RIA) in acute and chronic hepatitis $B$ and in blood donors. Hepatology 1983;3:337-42.

${ }^{9}$ Rizzetto M, Shih JWK, Verme G, Gerin GL. A radioimmunoassay for $\mathrm{HBcAg}$ in the sera of HBsAg carriers: serum $\mathrm{HBcAg}$, serum DNA polymerase activity and liver $\mathrm{HBcAg}$ immunofluorescence as markers of chronic liver disease. Gastroenterology $1981 ; 80: 1420-7$.

10 Rizzetto M, Shih JWK, Gocke DJ, Purcell RH, Verme G, Gerin JL. Incidence and significance of antibodies to delta antigen in hepatitis B virus infection. Lancet 1979 ;ii:986-90.

$"$ Smedile A, Lavarini C, Crivelli O, Raimondo G, Fassone M, Rizzetto M Radioimmunoassay detection of IgM antibodies to the HBV-associated delta antigen. Clinical significance in delta infection. 7 Med Virol 1982; 9:131-8.

12 Verme G, Piccinino F, Rizzetto M, Giusti G. I portatori dell'antigene Australia (HBsAg): problemi attuali. Il Fegato 1980;27:81-114.

${ }^{13}$ Bedarida G, D'Agostino F, Bianchi M, et al. Unexpected lower prevalence of HBsAg in diabetics than in controls. A study on 2465 patients. $L a$ Ricerca 1982;12:409-15.

14 Miyakawa Y, Mayumi M. Characterization and clinical significance of HBeAg. In: Vyas GN, Cohen SN, Schmid R, eds. Viral hepatitis. Philadelphia: The Franklin Institute Press, 1978:192-201.

15 Rizzetto M, Canese MG, Gerin JL, London WT, Sly LD, Purcell RH. Transmission of hepatitis B virus-associated delta antigen to chimpanzees. $\mathcal{F}$ Infect Dis 1980;141:590-602.

(Accepted 2 August 1983)

\section{SHORT REPORTS}

\section{Arthropathy induced by beta blockade}

Few reports on arthropathy induced by beta blockade have been published. Pain and swelling of both knees developed in a man who took practolol for nearly three years after a myocardial infarction, subsided when he stopped the drug, and recurred when he took it again. ${ }^{1}$ Polyarthritis has been described in association with propranolol and oxprenolol ${ }^{2}$; the same author described a similar case attributable to propranolol.

Paradoxically, propranolol exerts a favourable effect on arthritis. ${ }^{3}$ The mechanism of action remains to be established. The effect probably occurs as a result of the membrane stabilising or anaesthetic properties of the drug; beta receptor blockade does not seem to be a factor. ${ }^{4}$

In 1980 I began to look for possible cases of arthropathy induced by beta blockade after a patient's shoulder complaint subsided soon after metoprolol was stopped.

\section{Patients, methods, and results}

Patients were considered to have suffered from arthropathy induced by beta blockade if their joint symptoms developed during administration of a beta blocker and subsided only after the drug was stopped (or after a change to a different beta blocker). All the patients were seen at this hospital or my private surgery and came from a region of about 25000 inhabitants

Eighteen patients (mean age 64 years, range 45-74 years) were seen with arthropathy induced by beta blockade; six had been taking beta blockers for more than five years and seven for more than two years. The primary indication was hypertension or coronary heart disease or both. In every case an attempt was made to exclude other causes of joint symptoms by radiology and serological tests for rheumatoid disease.

Fifteen patients had symptoms affecting the shoulder joint. These consisted mainly of discomfort on moving the arms and limitation of movement due to pain when the patient tried to raise the arm above the horizontal. Some patients complained of pain and stiffness at rest. None had joint effusion. Radiological examination generally disclosed slight thickening of the soft tissues surrounding the shoulder joint. Nine of the 15 had symptoms in other joints as well. Apart from the shoulder, the knee was most commonly affected (six patients). Five patients had symptoms of polyarthritis. Two patients complained of swelling and stiffness of the small finger joints.

The primary beta blocker used was metoprolol (table). Those patients who developed joint symptoms with propranolol were given metoprolol as the first alternative. All reported exacerbation of the joint symptoms. Associated symptoms such as dry mouth and eye complaints were common as well (table). Despite attempts to substitute other beta blockers for metoprolol and propranolol the same pattern of adverse effects tended to recur, so that beta blockade eventually had to be stopped in 12 of the 18 patients. All the joint symptoms (and the associated complaints) resolved promptly in the patients.

\section{Comment}

Joint disturbance must be considered to be a common adverse effect associated with beta blockade. Other adverse effects, notably eye symptoms, dry mouth, and Raynaud's phenomenon, were also common, which points to some common factor, most probably dehydration of mucous membranes and synovia induced by the drug. 